Georgetown University Law Center

Scholarship @ GEORGETOWN LAW

1997

\title{
Ethics in ADR Representation: A Roadmap of Critical Issues
}

Carrie Menkel-Meadow

Georgetown University Law Center, meadow@law.georgetown.edu

This paper can be downloaded free of charge from:

https://scholarship.law.georgetown.edu/facpub/1766

4 Dispute Resol. Mag. 3

This open-access article is brought to you by the Georgetown Law Library. Posted with permission of the author. Follow this and additional works at: https://scholarship.law.georgetown.edu/facpub

Part of the Dispute Resolution and Arbitration Commons, and the Legal Ethics and Professional Responsibility Commons 


\title{
EthICS IN ADR REPRESENTATION: A Road Map of Critrical Issues
}

\author{
By Carrie Menkel-Meadow
}

M

uch ink has been spilled in recent years on the ethics and standards that should be applied to third party neutrals acting as mediators, arbitrators or evaluators in a variety of "alternative" (or as we now say, "appropriate") dispute resolution fora.' Much less ink has been spilled on what could be an even more difficult issue: Should different ethical standards be applied to lawyers who serve as "representatives" inside ADR processes than the usual rules applied to lawyers in their roles as "advocates" or "counselors" in the more traditional adversary system?

At the threshold level it is important to consider what asking this question means. Can/should lawyers be mandated by ethical standards or rules (or other legal measures, such as liability rules) to "behave" differently in ADR than in "ordinary" representation?

For those of us who want to change lawyers' behavior in mediation to include more creative, synergistic, problem-solving, integrative and candid negotiating activities, ${ }^{2}$ is a change of "ethics" rules the best (or only) way to accomplish such cultural change, or should behavioral change be left to other, more effective means, such as education, different incentive struc-

Carrie Menkel-Meadow is Professor of Law at Georgetown and UCLA Law Schools. She is also the Chair of the CPR-Georgelown Commission on Ethics and Standards in ADR, which is drafting model rules to deal with some of these issues, and CoDirector of the UCLA Center for the Study of Conflict Resolution. She can be reached by $\theta$-mail at meadow owpgate. law3,gegrgetewn.edu. Copyright Carrie Menkel-Meadow (1997). tures ${ }^{3}$ (such as reverse contingent or "bonus" fees based on settlements or court-mandated ADR programs), or changing client preferences (such as the use of ADR programs as the expression of "Total Quality Management" within some corporate and organizational client settings)?

For some, there is an even more controversial and prior question: Should the goals of representation within $A D R$ be any different than those in the more traditional adversarial

\section{Should the goals of representation within ADR be any different than those in the more tradl- tional adversarial setting?}

setting? Doesn't a client (and her lawyer) have the "right" to maximize her interests within a mediation. an arbitration and an early neutral evaluation? In the many recent efforts, in new books, articles and training programs, to train lawyers to be "mediation advocates," (a term I have found as oxymoronic as others find "evaluative mediation"), the assumption seems to be that mediation is just another form of adversarial hearing that needs to be planned and prepared for, perhaps with just al lew modifications, including client-role preparation and divisions of labor between lawyer and clients for presenting the case, making arguments, addressing the



other side, suggesting proposals or agreeing to solutions.

\section{Different Processes, Different Ethical Rules?}

It is sad to say that my prediction of almost 10 years ago, that ADR processes would be "co-opted" by traditional adversarial processes, rather than become differently organized and motivated problem-solving processes, has come true.' In recent years I have watched lawyers write letters "filing an ADR proceeding against" another party and threatening to "change their mediation strategy" if a particular demand or proposal is not adhered to.

Clearly, the language of traditional adversarial practice has taken over or conquered many processes that were supposed to be based on different foundational principles of seeking joint gain, attempting to find Pareto optimal solutions, causing less harm to the parties and exploring solutions to underlying problems that were not exclusively legally based, but considered more of the parties' underlying economic, business, social, psychological, moral or political needs and interests. ${ }^{6}$

As a result, even mediation which was supposed to have been the most "alternative" to traditional adversary practice, and thus differs from the more conventional and adversarial "ethics" of arbitration, for example can now be called "adversarial" mediation. at least in some contexts, where lawyers on "opposite" sides clearly prepare briefs or "mediation submissions," plan opening statements and case narratives, ask for third party neutral evaluations and direct their attention to the mediator, when they should be planning, with their clients, 
how to negotiate and problem-solve with "the other side." Mediation, is after all, still considered to be facilitated negotiation, seeking agreement and settlement and not a "decision-seeking" process.

As I have argued in the third party neutral context,' not all ADR is alike and we may have to take account of the different foundational principles, organization or "logics" of different processes to consider what ethics are appropriate in each. Thus, while it might make sense to talk about "arbitration advocacy" (and traditional adversarial ethics therein, with little modification of the Model Rules of Professional Conduct), I prefer to talk about "representation" in mediation, not mediation advocacy, to at least attempt a semantic distinction between the role of the lawyer in a decisionseeking (adjudicative) environment from a settlement seeking (problemsolving or negotiation) process in which a lawyer may still "represent" a client, but with different purposes, and presumably with a different audience (the "other side(s)" and its lawyers, not the mediator) in mind.

\section{The Basic Ethical Duties}

So, the question is what obligations do lawyer-representatives in negotiation have and do these obligations or ethical requirements change with the presence of a third party mediator?

At the most minimal level, lawyers may not knowingly make a material misrepresentation of a material fact or law (Model Rule 4.1) (with exceptions for "puffing" and other conventional negotiation activities stated above); they may not fail to disclose a material fact when disclosure is necessary to avoid assisting a criminal or fraudulent act by a client (Rule 4.l(b) (unless disclosure would otherwise be protected by the confidentiality requirements of Rule 1.6), and they may not communicate with a party known to be represented by a lavyer (Rule 4.2).

Lawyers also must maintain client confidences, unless the client authorizes them to reveal information (Rule
1.6), which has implications for what lawyers may disclose to mediators, as well as to third parties, potentially involving either "double" confidentiality or privilege issues or conflicting confidentiality duties in mediation and in client representation.

Lawyers must also inform clients about the status of a matter so that a client may make informed decisions about the case (Rule 1.4) and a lawyer must abide by a client's decision as to whether to settle a matter (Rule 1.2, a rule which has been interpreted to mean that a lawyer must transmit all settlement offers to the client). disclose "to a tribunal" legal authority in the controlling jurisdiction known to the lawyer to be "directly adverse to the position of the client." Is a courtsponsored mediation such a "tribunal?" Is an early neutral evaluation session conducted under a court program's requirements, but held in a private law office, such a tribunal?

Similarly, if the purpose of this rule is to protect a court from making an incorrect legal decision (with potential adverse precedential effects) should it make a difference whether the ADR proceeding is an arbitration (where a decision will be rendered,

\section{Beyond the Model Rules, a lawyer's ethlcs in mediation will depend upon a personal sense of proper advocacy, cllent expectations, substan- tive rules and contractual arrangements.}

How the lawyer behaves in negotiation and in mediation, beyond these "minimal" ethical requirements remains subject only to the lawyer's sense of what is appropriate "representation" or advocacy, what a client might expect (based on the client's familiarity with or philosophy about ADR processes), any independent substantive or process rules (such as discovery or disclosure requirements in court annexed programs) and whatever contractual or process arrangements are agreed upon by the parties in an ADR proceeding.

This means some forms of mediation or ADR might impose "higher" standards of disclosure or conduct by contract (agreement of the parties, process rules of the third party neutral) or court rules (some courts and states have attempted, by statute or court rule, to regulate conduct and behavior such as mandated disclosures or requirements for "good faith" participation ${ }^{8}$ ).

There remain some tricky ambiguities in the application of the traditional rules of ethics to ADR. Model Rule 3.3 requires a lawyer to but not published) or a mediation (where the mediator has no authority to render a "decision" on the law)? Should there be disclosure of such adverse authority if the ADR process is an "early neutral evaluation,"which is intended to take account of the substantive law? Or an evaluative mediation, in which the parties will ask the mediator to opine on legal merits, as well as facts, or other party interests?

\section{Accountability in ADR}

Is there an argument that there should be greater candor (both with respect to law and fact) in mediation sessions where there will be no court scrutiny of the settlement (like the argument for greater candor in negotiation above), but will be "presided" over by a third party neutral who may care about or feel some responsibility for the agreement that is reached?" Or, is mediation just like a negotiation, in which the parties must accept whatever advocacy resources they have, knowing these may affect the outcome? Does it make a difference whether the ADR takes 
place privately or in a court-sanctioned selting? Or if one of the parties is not represented?

Recently, the ethical requirements with respect to client counseling have been expanded in some states by court rulings, ethics rule changes or ethics committee opinions to require counsel to advise clients about the possibilities of ADR and various methods of settlement that might be considered more appropriate than litigation in some cases." Requests by one side to consider the use of ADR must, in such cases, be communicated to one's client just like a specific settlement offer under Model Rules I.2 and 1.4. If such rulings are adopted more widely (and enforced) they may do more to increase the use of ADR than all prior efforts. It may no longer be a sign of "weakness" to suggest ADR and a lawyer may not unilaterally decide to avoid other methods of dispute resolution than the one he or she is most familiar with.

With the expanding nature of roles to be played by counsel in resolving disputes, there is also greater complexity with respect to the ethics and rules of conflicts of interest. Can a lawyer who represents one party against another in a mediation that settles then represent another party against the former opponent when the lawyer has learned confidential information about the opponent in mediation?" Can a lawyer who serves as a mediator between two parties subsequently represent one of those parties in a later matter, whether related or unrelated?'2 Can a lawyer who represents a client ever mediate a matter involving that client and another?"13

Similarly, are these conflicts issues different when a single counsel "switches" roles from representative to arbitrator or vice versa? If a single lawyer cannot switch roles without a conflict of interest, when must the whole firm be disqualified, or will a conflicts "screen" sufficiently shield the involved lawyer to allow continued representation by other firm members? ${ }^{14}$

Even without role switching there may be complex conflicts of interest rules inherent in the use of ADR. What if, during a mediation, counsel agrees to a confidentiality provision (which might even include a protective order) and learns a critical fact from the defendant? If the mediation fails, is counsel able to effectively represent her client without using this fact, as promised? 15 $^{5}$

\section{A Problem of Zeal}

Most of the ethical dilemmas that remain to be revealed, if not resolved, in the use of ADR within a framework of adversarial advocacy might be "reduced" to the question of when can/ should a lawyer-representative turn off the "zeal" to be an effective problemsolver?

In my ideal world, ethics rules might require lawyers to be creative, ${ }^{16}$ looking for solutions that maximize lead us into conflicts of ethics.

In a recent mediation I participated in, counsel prepared excellent interest-based submissions on the underlying problem to be solved (not briefs on the narrow legal issue) and participated in good faith in face to face mediations, but when they returned to their "adversarial dens" (their law firms), the next round of written submissions virtually destroyed whatever progress we had made by issuing written adversarial and positional darts into the tentative and very broad-based proposals for consideration. Here the adversarial analysis got in the way of the solutionseeking synthesis; overly critical judgments appeared too early in the "brainstorming" process.

Ultimately. good ADR behavior may be learned, from educational programs, from modeling and de-

\section{The clash of values represented In what our basically adversarlal code of zeal requires and what good problem-solving recommends will Inovitably lead us into conflicts of ethics.}

client gain while causing the least harm to others - or, even more ideally, that maximize gain (or minimize harm) to all those involved in a legal problem, ${ }^{17}$ to be candid with their clients, mediators, arbitrators, judges and opponents, and to refuse to insist on an agreement or outcome that causes injustice or is worse than one the parties could achieve in some other way (such as litigation).

On the other hand, this is not my ideal world and $I$ am not so naive as a legal ethicist to think that we can change behavior by changing a few ethics rules. (Is legal behavior now anywhere close to what the rules provide?) Yet, I also know, as an ADR practitioner, as well as an ethicist, that the clash of values represented in what our basically adversarial code of zeal requires from what good problemsolving recommends will inevitably scriptions of success and from the recognition that a different kind of "strategy" may be necessary in different forms of ADR, depending on such factors as the parties involved, the issues and the nature of the dispute or problem at hand. In the example above, counsel might have thought more about the differences between the written and oral word in ADR, as they must in more traditional forms of advocacy. ${ }^{18}$

Like Ms. Manners (my version), I would prefer that lawyers behaved "better," or at least differently in solution-seeking processes. Advocacy has its place, but the rules that work for the criminal defense lawyer may not work for the class action or in-house organizational lawyer, and will not work for the lawyer-representative in some forms of ADR. We are in the midst of significant cultural changes in 
the law and its practice. Some of these changes will eventually have to be reflected, I believe, in ethics codes that are more sensitive to context and different venues of practice.

It may, however, be too early to regulate by ethics codes, except at the obvious margins of clashes in professional expectations (confidentiality and information disclosure; conflicts) or where there is enough overlap of duty between an advocate and a "representative" in ADR (counseling about client objectives). We may have to leave the rest to contract, common law development and more experience with the different processes before we

Significant cultural
changes in law and
its practlce may
force new ethical
standards that are
more sensitlve to the
different contexts
and venues in which
lawyers practice.

can turn behavioral exhortations into commandments.

Can/should a mediator require lawyers to engage in only "integrative" bargaining, rather than "distributive bargaining" in his venue?" $\mathrm{Can} /$ should a mediator or evaluator require counsel to be absolutely candid with him? With other parties? As long as traditional trial or adversarial practices remain the "default" position for our system and the cultural image from which our ethics rules are derived, our behaviors will likely turn on our own individual ethics and commitments to different forms of dispute resolution.

In my ideal world the "problemsolvers" will inherit the Earth, but I think we are more likely to get there by demonstrating the instrumental, as well as humanistic, advantages of doing so than by formally requiring compliance with an ethical code that doesn't match our behavioral or cultural evolution (yet).

\section{Endnotes}

'. See, e.g., AAA-ABA-SPIDR Joint Standards of Conduct for Mediators (1994); American Arbitration Association, Ethical Standards for Commercial Arbitrators (1977); Symposium, The Lawyer's Duties and Responsibilities in Dispute Resolution, 38 So. Tex. L. Rev. 375-801 (1997); C. Menkel-Meadow, Professional Responsibility for Third Party Neutrals, 11 (9) Alternatives 129 (1993).

2. See, e.g., C. Menkel-Meadow, Toward Another View of Legal Negotiation: The Structure of Problem-Solving, 31 UCLA L. Rev. 754 (1984); Rogea Fisher and William Uhy, Getting To Yes (2ed. W. Patton, ed. 1991).

3. See R.J. Gilson and R.H. Mnookin, Disputing Through Agents: Cooperation and Conflict Between Lawyers in Litigation, 94 Colum. L. Rev. 509 (1994) (arguing that lawyers' repulations for cooperation in legal problem-solving will enhance their professional market share).

4. See, e.g.. John W. Cooley, Mediation advocacy (1996); Eric Galton, Repaesenting Youf Client in Mediation (1994).

5. See C. Menkel-Meadow, Pursuing Selllement in An Adversary Cullure: $A$ Tale of Innovation Co-Opted or "The Law of ADR," 19 Fla. St. L. Rev. 1 (1991). 6. See C. Menkel-Meadow, The Trouble with The Adversary System in a PostModern, Multi-Cultural World, 38 Wm. \& Mary L. Rev. 5 (1996).

7. See C. Menkel-Meadow, The Silences of the Restatement Governing Lawyers: Lawyering As Only Adversary Practice, Geo. J. Leg. Ethics (1997); ld., Ethics in Dispute Resolution: New Issues, No Answers From the Adversary Conception of Lawyers' Responsibilities, 38 So. Tex. L. Rev. 407 (1997).

B. See Edward F. Sherman, CourtMandated Allernative Dispute Resolution: What Form of Participation Should be Required? 46 SMU L. Rev. 2079 (1993).

9. See, e.g., Lawrence Susskind, Environmental Mediation and the Accountability Problem, 6 Vt. L. Rev. 1 (1981).

10. See, Arthur Garwin, Show Me the OHer, ABAJ, June 1997 at 84; Col. Ethics Handbook, Rule 2.1 (1996); Jackson v. Philadelphia, 858 F. Supp. 464 (E.D. Pa. 1994); Pennsylvania Bar Assn.. Ethics Op. 90-125; Kan. Bar Assn.. Comm. On Ethics-Advisory Services, Op. 94-01; Mich. State Bar Comm. On Prof'l and Judicial Ethics, Informal Op. Rl-255 and RI-262.

". In Barajas v. Oren Reality and Develop. Co., 67 Cal. Rptr. 2d 62 (Ct. Of App. 2nd Dist.), the trial court said no, but the court of appeals reversed and said that plaintiff's counsel could represent both plaintiffs because the legislature did not intend a mediation disqualification rule to flow from confidentiality protections. The court indicated that when mediations fail, parties have to abide by non-use of confidential information they have heard during the mediation process and the same rationales would apply in a new, but related, case against the same party.

12. See, e.g., Polysoftware v. Su, $880 \mathrm{~F}$. Supp. 1487 (D.Utah, 1995); McKenzie Const. V. St. Croix Storage Corp. $961 \mathrm{~F}$. Supp. 857 (D.V.I. 1997); Stale v. Tolias, 929 P. 2d 1178 (Wash. 1997) (all holding that lawyers who had previously served in mediative capacity were disqualified from subsequently acting as representatives); see also Cho v. Superior Court, 45 Cal. Rptr. 2d 863 (1995) (disqualifying a law firm when a judge who had handled settlement conferences in a matter between Iwo parties subsequently joined the law firm representing one of the parties).

13. This problem would seemingly be "waivable" if all parties consent, but would an "opponent" ever believe that a former partisan representative could ever be "neutral" with respect to a former or worse, continuing client.

14. These conflicts questions are difficult and subtle and may not be answerable with reference to the current attorney conflicts rules. The CPR-Georgetown Commision on Ethics and Standards in ADR is currently drafting model contlicts rules for attorneys who "switch" roles between "neutral

third party roles and advocacy roles, and for law firms who contain both kinds of lawyers.

15. See Model Rule 1.7 (b); GTE Directories Serv. Corp. v. Pacific Bell, 135 F.R.D. 187 (N.D. Cal. 1991); M. Sonnenleld \& P. Greco, Confidentiality and ADR: Protecting the Privacy of the Proceedings, Metropolitan Corporate Counsel (August, 1997) at page 6.

${ }^{16}$. In addition to analysis, lawyers need to learn how to synthesize, be creative and to look for new ways to solve problems. See, $\theta . g$., James Adams, Conceptual Blockbusting (1986); Donald Schon \& Martin Rein, Frame Reflection: Toward the Resolution of Intractable Policy Controversies (1994); Robert Olson, The Art of Cheative Thinking (1980); Lawrence Susskind and Pataick Field, Dealing With An Angry Public (1996); C. MenkelMeadow, To Solve Problems, Not Make Them: Integrating ADR in the Law School Curriculum, 46 SMU L. Rev. 1995 (1993). 17. Here I am focused on problems which are susceptible to a negotiated or other "ADR" solution. I do not here speak lor the class of cases that truly require adjudicated rulings from courts or continued court monitoring for execution of judg. ments, agreements etc. Not all cases are appropriate for settlement or ADR processes.

18. See Paul Bergman, The War Between the States (Ot Mind): Oral versus Textual Reasoning, 40 Ark. L. Rev. 505 (1987).

19. I thank the Honorable Edmund $B$.

Spaeth, Jr. for this example. 